\title{
The Textual Connection between 4Q380 Fragment 1 and Psalm 106
}

\section{Pajunen, Mika}

Vandenhoeck \& Ruprecht

2011

Pajunen , M 2011, The Textual Connection between 4Q380 Fragment 1 and Psalm 106 . in N David, A Lange , K De Troyer \& S Tzoref (eds), The Hebrew Bible in Light of the Dead Sea Scrolls . Forschungen zur Religion und Literatur des Alten und Neuen Testaments, no. 239 , Vandenhoeck \& Ruprecht, pp. 186-202.

http://hdl.handle.net/10138/231808

publishedVersion

Downloaded from Helda, University of Helsinki institutional repository.

This is an electronic reprint of the original article.

This reprint may differ from the original in pagination and typographic detail.

Please cite the original version. 


\author{
Mika S. Pajunen \\ University of Helsinki
}

\title{
The Textual Connection between 4Q380 Fragment 1 and Psalm 106
}

The first edition of manuscript 4Q380 came out in 1986. It was prepared by Eileen Schuller who later also published the official DJD edition of the text and still remains the only scholar to have worked with the text in detail. ${ }^{1}$ The manuscript consists of seven fragments written in a formal Middle to Late Hasmonean hand. ${ }^{2}$ The fragments are quite small with fragment 1 being the only sizeable piece. From the two surviving beginnings ( 1 ii $8 ; 4$ 1) and the poetic style it can be deduced that the manuscript contains a collection of psalms. Schuller labeled the text Non-Canonical Psalms A because the remaining parts of the collection do not include any of the psalms known from other Psalters or collections. ${ }^{3}$ There is nothing in the content of the psalms that would suggest their writer(s) to have been a member of the Qumran movement. Their composition should probably be dated roughly to the Persian or Early Hellenistic period as has been suggested by Schuller. ${ }^{4}$ She has given two suggestions for the principle behind the psalm collection in 4Q380. If 4Q380 and another collection of previously unknown psalms, 4Q381 Non-Canonical Psalms B, are separate collections, she offered the possibility that 4Q380 might in that case be a compilation of psalms ascribed to different prophets because one of the psalms is ascribed to Obadiah (1 ii 8). On the other hand, if the manuscripts are copies of the

\footnotetext{
${ }^{1}$ For the editio princeps in the DJD series, see Eileen M. Schuller, "4QNon-Canonical Psalms A," in Qumran Cave 4. VI Poetical and Liturgical Texts, part 1 (DJD 11; ed. Carol Newsom and Eileen M. Schuller; Oxford: Clarendon, 1998), 75-85. For a fuller discussion on many of the themes, see Eileen M. Schuller, Non-Canonical Psalms from Qumran: A Pseudepigraphic Collection (HSS 28; Atlanta: Scholars Press, 1986). For her other publications on this manuscript, see eadem, "4Q380 and 4Q381: Non-canonical Psalms from Qumran," in The Dead Sea Scrolls: Forty Years of Research (ed. Devorah Dimant and Uriel Rappaport; STDJ 10; Leiden: Brill, 1992), 90_ 99; eadem, "Qumran Pseudepigraphic Psalms (4Q380 and 4Q381)," in The Dead Sea Scrolls: Hebrew, Aramaic and Greek Texts with English Translations. Vol. 4A, Pseudepigraphic and NonMasoretic Psalms and Prayers (ed. James H. Charlesworth and Henry W.L. Rietz; Tübingen: Mohr Siebeck, 1997), 1-39.

2 Schuller, "4QNon-Canonical," 76.

${ }^{3}$ Schuller, "4QNon-Canonical," 77

${ }^{4}$ Schuller, "4QNon-Canonical," 78.
} 
same collection then it could be a non-Davidic supplement to the Psalter. ${ }^{5}$ The connection between the two psalm collections is highly unlikely because there is no overlapping text between them and the characteristic features of the larger collection, 4Q381, are not present in 4Q380. However, the focus of this article is not on this supposed connection between the two collections.

This article concentrates on the best-preserved psalm in 4Q380, which, because of this status, also has a central role when trying to understand the collection as a whole. One of the most interesting and important features of this psalm is its connection with MT Psalm 106. There is a parallel passage found in these psalms (4Q380 1 i 7-11; Ps 106:2-5) that implies that one is likely to be dependent on the other. The direction of this influence is not so clear. Schuller argues in favor of seeing the passage in 4Q380 as a use of Psalm 106, but does not discuss the relationship in great detail. ${ }^{6}$ The opposite view, that Psalm 106 is in this case dependent on the psalm in 4Q380, has been suggested by George Brooke. ${ }^{7} \mathrm{He}$ offers some explicit reasons for this argument that derive from the differences between the two psalms in the connecting passage. His arguments do tip the scales in the direction he proposes, but some of them can also be turned around and the issue remains contested. ${ }^{8}$

Brooke's arguments are weighty enough to merit further study and the aim of this article is to analyze thoroughly this textual connection. First, in order to have a more complete understanding of the psalm partly preserved in 4Q380 the text of the fragment is studied. Then the connection between the two texts is analyzed with an emphasis on the differences found between the psalms within the parallel text. Additionally, the interpretative method used previously by Adele Berlin, Esther Chazon, and Julie Hughes in their studies of allusions and quotations in poetic texts will be employed here. ${ }^{9}$ Central to this strategy is the acknowledgment that in poetry allusive

\footnotetext{
${ }^{5}$ Schuller, "4Q380,"1-2.

${ }^{6}$ Schuller, Non-Canonical, 32-34, 257.

${ }^{7}$ George Brooke, "Psalms 105 and 106 at Qumran," RevQ 54 (1989): 267-92.

${ }^{8}$ Actually, although Brooke's article is listed in the bibliography of several commentaries no one has taken up the argument to support or reject it, see Erhard S. Gerstenberger, Psalms part 2 and Lamentations (FOTL XV; Grand Rapids: Eerdmans, 2001), 245 and Schuller, "4QNonCanonical," 80.

${ }^{9}$ Adele Berlin, "Qumran Laments and the Study of Lament Literature," in Liturgical Perspectives: Prayer and Poetry in Light of the Dead Sea Scrolls, Proceedings of the Fifth International Symposium of the Orion Center, 19-23 January 2000 (ed. Esther G. Chazon, Ruth Clements and Avital Pinnick; STDJ 48; Leiden: Brill, 2003), 1-17. Esther G. Chazon, "The Use of the Bible as a Key to Meaning in Psalms from Qumran," in Emanuel. Studies in Hebrew Bible, Septuagint and the Dead Sea Scrolls in Honor of Emanuel Tov (ed. Shalom M. Paul, Robert A. Kraft, Lawrence H. Schiffman and Weston W. Fields; Leiden: Brill, 2003), 89. Julie A. Hughes, Scriptural Allusions and Exegesis in the Hodayot (STDJ 59; Leiden: Brill, 2006).
} 
words do not lose their previous contexts or their connotations and that an allusion pulls meaning from one context and inserts it into another. ${ }^{10}$ The allusions and quotations offer a perspective on what the composer wanted to emphasize by picking that particular text and more importantly what the use of a specific text would have meant for an audience that already knew the source text. With the combination of these methods it will be argued that Brooke is correct in his suggestion and the 4Q380 psalm should be seen as a source for Psalm 106. Finally, I will briefly describe the implications of this conclusion for understanding the connection between Psalm 106 and 1 Chronicles 16:34-36, and for understanding the nature of the collection of psalms in 4Q380.

\title{
1. The Psalm in 4Q380 Fragment 1
}

\author{
Text and Translation ${ }^{11}$
}

Fragment 1, col. i

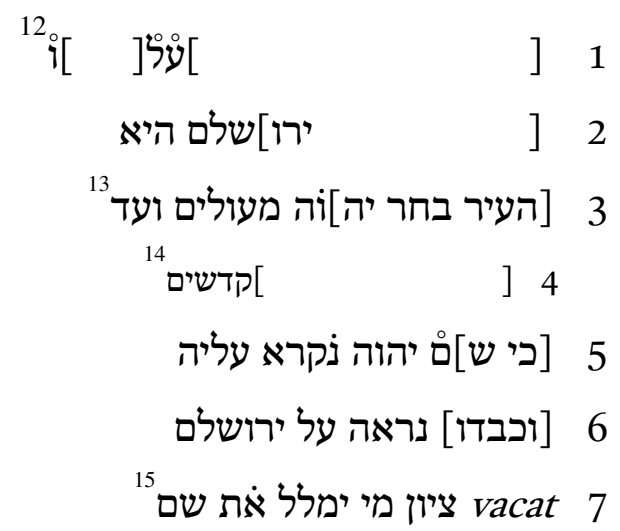

\footnotetext{
${ }^{10}$ Berlin, "Qumran Laments," 17.

11 The text has been read with the aid of different photographs possessed by Schuller as well as electronic images, but the original fragment was also consulted in 2008.

12 Traces of three letters can be seen on the line. The angle of the stroke makes $y$ the most likely choice for the first letter. The second letter is written on top of the horizontal stroke of $y$, which suggests $ל$ although $\mathrm{r} /$ remains another possibility. The last letter of the line appears to be either $ו$,' or the lower part of $ל$.

13 As Schuller, "4QNon-Canonical," 80, suggests, the divine choice of Jerusalem should be reconstructed somewhere on lines 2-3.

${ }^{14}$ Quite probably the restoration should continue the thought of Jerusalem as a chosen city as well as a more active role for God than on lines 5 and 6 . Some possible options would be: 'to dwell in the midst of the holy of holies'/ 'as a dwelling place for ...'/ 'to dwell with the holy ones.'

15 Schuller, "4QNon-Canonical," 79-80, argues that, although there is no sign of damage on the leather, a letter or two should be reconstructed before 'Zion' as the margin would otherwise be too irregular. First of all, the margin is somewhat irregular as can be seen at the beginning of line 11 and slight variation can also be observed in column II. Second, as pointed out by Schuller there is
} 


\author{
8 \\ 9 \\ 10 להראות בטּוב \\ 11 [בח]יْריוּ לִשי[מח בשמחה] \\ 12 עם נחלתו \\ col. II \\ 1 \\ 2 כי הוא זה שמרו אמْ[ריו] 17 \\ 3 אשר לכול ב[נ][י ישראל va]cat לא]

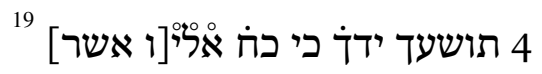 \\ 5 עושה טוב[ה] ושנאי רעים עדْ[ מתי] \\ 6 תחפצו לעש[ו]"ن רעה פן יְרבך עוֹ[ז]20
}

no trace of a letter preceding $צ$ or any sign of damage on the leather. Therefore, 'Zion' should be read as a vocative, used as a transition from praising the city to describing the bliss of the chosen people living there. Furthermore, it seems that the scribe used vacats between stanzas within psalms and between different psalms and thus the space preceding 'Zion' should be seen as an indentation before a new stanza. Asimilar indentation before the beginning of a new psalm in frg. 41 was probably left because the previous psalm ended before filling half the available line and the scribe did not want to waste space by leaving another whole line blank. In column ii 7 he left a whole line blank between psalms and on the next line a sizeable vacat after the superscription, clearly indicating the use of vacats in this manuscript. Because of the narrow columns and poor preservation of the text it is next to impossible to evaluate whether there are other vacats in the text, but the blank space after 'Israel' on 1 ii 3 is long enough to be seen as a vacat between stanzas especially as it seems to conclude a line of thought.

16 The first letter of the third word is either an $\boldsymbol{k}$ or a $\lambda$. The partly visible slanting vertical stroke after the previous word would also leave other options open, but there is a trace of a stroke connecting to the leg of 7 that eliminates the other possibilities. $\lambda$ is the more likely of the two as there should probably be some trace left of the upper right part of $\aleph$. The last visible stroke on the line curves slightly and it could belong at least to a $ו$ or a $ל$ frequently reaches the same line as the other letters in this manuscript so the choice depends on the reconstruction. Whether the preceding word is read as it is here or as אדם 'man' does not affect the fact that the next line needs an antecedent and from what remains the column contrasts the ways of the listeners with the ways of the pious who do God's will. In accordance with this understanding and the narrow column width אלוהים 'God' is reconstructed in the lacuna.

${ }^{17}$ One of the possible reconstructions offered by Schuller, "4QNon-Canonical," 81, would lay out a contrast between the pious among the Israelites who observe the words of God and those who do not.

${ }^{18}$ In view of the contrast between the listeners and the pious, the negative should be reconstructed with Schuller, “4QNon-Canonical," 81.

19 The reconstruction is done mainly on the basis of the previous colon having a כי-אשר structure and because this would again reinforce the contrast between the listeners and the pious. 


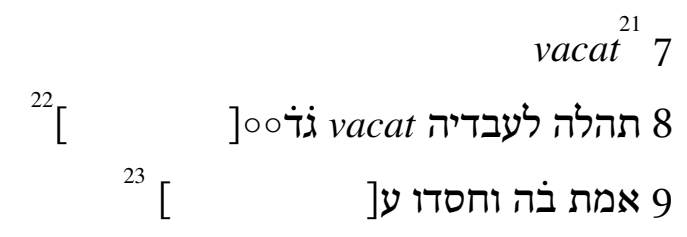

Translation

Col. i

1. $[\ldots] \ldots[\ldots] \ldots$

2. [... Jeru]salem, that is

3. [the city Yah]weh [chose] forever and ever

4. [...] holy ones

5. [for the na]me of Yahweh is invoked upon it

6. [and his glory] is seen upon Jerusalem.

7. vacat $\mathrm{O}$ Zion! Who can utter the name of

8. Yahweh and who are the ones to declare all [his] praise?

9. Yahweh [remem]bered him ${ }^{24}$ in his favor. And visited him

\footnotetext{
${ }^{20}$ The endings of the last two lines of the psalm are extremely hard to figure out, as the traces offer multiple options for interpretation. The last visible letter on line 5 could also be ' or 1 . In line 6 the פן is the best reading, but not certain; the letter could also be כ כ כ כ (by the size) or מ. The penultimate word is the hardest to read. The first letter is clear as is the ב, but the second and the last are not. The last letter is either $ר$ or a $\rceil$ without a long leg (as in ii 4). The letter is not the 7 suggested by Schuller, "4QNon-Canonical," 81 , as even when 7 is written in a smaller script it is very different from this letter (see ii 8). The second letter cannot be a $T$ for the same reason; nor is it the 1 supplied by Schuller, as the horizontal stroke extends upwards from the left tip indicating the letter is most likely a ר. It might perhaps also be $\mathrm{a} \zeta$ if the upper stroke is abraded, but $ר$ is the most likely option.

${ }^{21}$ There is a scribal mark in this line between the columns indicating a section break. It is similar to the 'horizontal fishhook' type of mark found in other compositions, e.g., 1QS, 1QH, 4Q496. For the use of section markers and the different marks used for this purpose, see Emanuel Tov, Scribal Practices and Approaches Reflected in the Texts Found in the Judaean Desert (STDJ 54; Leiden: Brill, 2004), 179-87.

${ }^{22}$ The scribe expresses some concern for space in these last two lines by writing a bit more neatly (but observe the size of the vacats) and he switches to writing on top of the dry lines possibly to squeeze in an extra line at the end of the column. There is a cut running through the middle of the last visible letters in the line. The letter after the vacat seems to be $\lambda$, as above the cut there is the ending of a vertical stroke without a head and below the cut the same stroke branches into two. The second letter has a vertical stroke visible below the cut with no sign of another one and above the cut a horizontal stroke with two faint traces of protrusions on top of it. These features correspond well to T. Only minute specks are left of the letters following these two.

${ }^{23}$ Only a small bit of the lower left part of the final visible letter is missing and the letter can be read as an almost certain $y$.
} 
10 to let him experience ${ }^{25}$ the prosperity of

11. his [chos]en ones, to make him [rejoice in gladness

(12.) with his inheritance $]^{26}$

Col. ii

1. (what) [can] he/it do for you (pl.)? Their fortune is God

2. for he is the one [whose] wo[rds] they kept

3. which are for all the ch[ild]ren of Israel. vacat

4. Your (sg.) hand will [not] save you (sg.) for strength is for the [one who

5. does goo[d] and the ones who hate the wicked. How[ long]

6. will you (pl.) delight to do evil lest puni[shment] is multiplied for you (sg.)?

7. vacat

8. A Psalm of Obadiah. vacat ...[...]

9. truth in it and his fidelity ...[...]

\subsection{The Dimensions of the Psalm}

The beginning of the psalm in 4Q380 fragment 1 is now lost, but the first preserved lines (i 2-6) praise Jerusalem. The psalm then moves on to praise the lot of the chosen ones whom God has remembered and visited (i 9-12) and who are able to declare his praises (i 7), i.e., to take part in the Jerusa-

24 The masculine suffix surely refers to the person able to utter the name and declare the praise rather than Jerusalem, which is referred to earlier in the psalm with the feminine suffix (I 5); so also Schuller, "4QNon-Canonical," 80.

25 The verb most likely has a sense of experiencing here rather than just observing; cf. Ps 60:5, 91:16 and of course 106:5

${ }^{26}$ Schuller reconstructs גויו 'his nation' in accordance with MT Psalm 106:5, but, as 4Q380 lacks

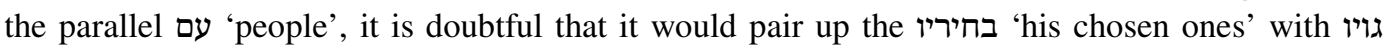
'his nation'. Gerstenberger, Psalms part 2, 238, has drawn attention to how seldom גו 'גוי וs used in direct connection with Yahweh. He notes that personal suffixes relating to Yahweh and attached to גוי occur only in Ps 106:5 and Zeph 2:9 and notably both times in parallelism with עם. Thus, a more likely candidate for the reconstruction of the verse in 4Q380 נחלתו 'his inheritance' also used in Ps 106:5. It would give the same sense of divine choice as the 'chosen'. Furthermore, it would fit well with the preceding theme of Jerusalem, as, e.g., Isaiah 66:10 speaks about rejoicing with Jerusalem. It is to be noted that the chosen ones are the ones who will inherit God's land (e.g., Isa 65:9). Another option worth considering would be to reconstruct: בשמחת עם נחלתו בשמח 'to rejoice in the mirth of the people of his inheritance' (cf. Deut 4:20) which would make the colon correspond more closely to the previous one. 
lem cult. A tough and important question is whether that is all that is left of the psalm or whether its ending is preserved in column two. Several observations speak in favor of seeing the columns as parts of the same psalm. ${ }^{27}$ First is the material aspect. The columns on 4Q380 are narrow (c. $5 \mathrm{~cm})$ and it would be unusual for them to be really tall as well. The other scrolls (cf. $4 \mathrm{QPs}^{\mathrm{b}}$ and $\left.4 \mathrm{QPs}^{\mathrm{d}}\right)^{28}$ with similar column width have roughly 20 lines or less and such is also likely here. Text from 11 lines survives, so there are probably fewer than ten lines between line 11 of column $i$ and line 1 of column ii. Therefore, there is probably not enough space to start and nearly complete an entirely new psalm. Fortunately, the connection between these columns does not have to rest solely on this hypothesis about the material remains because the content has similarities that suggest a connection.

One internal characteristic pointing towards the unity is the use of singular and plural elements for parallel ideas. This is a peculiar linguistic feature that might perhaps be a rhetorical device. It starts on column i 7 where there is first a singular (ימלל) and then a plural verb (וישמעו) for the parallel idea. In the following verses the merging of individual and plural is more logical as the single person is brought in to enjoy the benefits of a group, but still both the singular and the plural perspectives are present. In the second column there is a contrast between the people who are directly addressed by the psalmist and the pious obeying God's will. The people are addressed

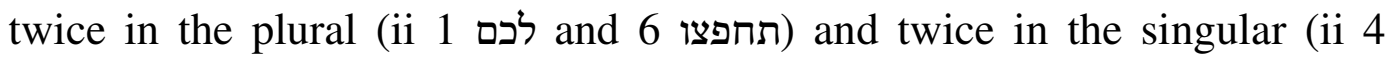
ירבך 6 and the pious are presented in the 3rd person plural (ii 1 (שמרו and except for line 5 where there is again first a singular participle (עושה) and then a plural (ושאני). This feature is too systematic to be accidental.

A connection is also present on the level of vocabulary, as there are many words relating to pleasure and enjoyment in both columns: experience prosperity (i 10), rejoice (i 11), fortune (ii 1), delight (ii 6). The final clue for a connection leads naturally to the next point of this analysis, i.e., to the parallel passages in 4Q380 and Psalm 106. Verse 3 of Psalm 106 gives an actual answer to the question presented in verse $2,{ }^{29}$ but there is nothing in 4Q380 i that would give a hint as to what qualifies the person for the divine

\footnotetext{
${ }^{27}$ A contrary view is held by Schuller, Non-Canonical, 257, who sees no connection between the texts in the two columns and judges them to be almost certainly two different compositions.

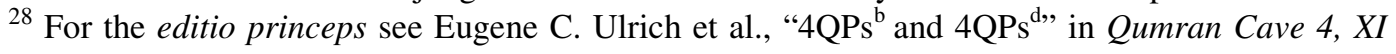
Psalms to Chronicles (ed. Eugene C. Ulrich et al.; DJD 16; Oxford: Clarendon Press, 2000).

29 This has also been noted by Leslie C. Allen, Psalms 101-150 (WBC 21; Dallas: Word Books, 1983), 47. Although most questions in the Psalms are rhetorical in nature and an answer is not expected, there is at least one other question which is related to the cult and receives an answer, i.e., Psalm 24:3. All these psalms give the answer by listing the qualities of the person who would be able to answer the question positively.
} 
visitation. However, 4Q380 ii does this. It speaks about trusting only in God, doing his will, doing good things and hating the wicked, and contrasts this with the actions of the audience or parts of it. Psalm 106 verse 3 gives the same answer in an abbreviated form using the same verbs (שמר and (עשה present in 4Q380 column ii and the same basic idea, i.e., those who observe God's will and do good all the time will be blessed.

\section{The Textual Connection between 4Q380 and Psalm 106}

$$
\text { Psalm 106:2-5 and 4Q380 } 1 \text { i 7-12 in Parallel }
$$

4Q380 1 i $7-12$

$$
\begin{aligned}
& 7 \text { ציון מי ימלל את שם } 8 \text { יהוה } \\
& \text { ושמעו כל תהלת[ו] } \\
& 9 \text { [זכ]רו יהוה ברצנו } \\
& \text { וויפקדהו } 10 \text { להראות בטוב } 11 \text { [בח]יריו } \\
& \text { לש[מח בשמחה } 12 \text { עם נחלתו }
\end{aligned}
$$

MT Ps 106:2-5

$$
\begin{aligned}
& 2 \text { מי ימלל גבורות יהוה } \\
& \text { ישמיע כל תהלתו } \\
& 3 \text { אשרי שמרי משפט } \\
& 4 \text { זכרני יהוה ברצון עמך } \\
& \text { פקדני בישועתך } \\
& 5 \text { לראות בטובת בחיריך } \\
& \text { לשמח בשמחת גויך } \\
& \text { להתהלל עם נחלתך }
\end{aligned}
$$

Translation

7. O Zion! Who can utter the name

of 8 . Yahweh and who are the ones

to declare all [his] praise? 9. Yahweh

[remem]bered him in his favor. And

visited him 10. to let him experience

the prosperity of 11 . his [chos]en ones,

to make him [rejoice in gladness (12.)

with his inheritance]
2. Who can utter the mighty

deeds of Yahweh, who can declare all his praise? 3. Bles sed are the ones who observe justice, the one righteous at all times 4. Remember me Yahweh in the favor of your nation, visit me in your salvation 5 . to let experience the prosperity of me your chosen ones, to let me 
rejoice in the gladness of

your people, to praise to

with your inheritance.

\subsection{Analysis of the Differences}

There are many differences between the two texts in the short parallel passage and these will next be analyzed one by one. First, in verse 2, Zion is not mentioned in Psalm 106. This is not surprising as the Psalm speaks or aims to speak from a diaspora/exile setting (most clearly seen in v. 47), and thus there would have been good reason to delete the explicit mention of Jerusalem. On the other hand, 'Zion' is used as a bridge word between stanzas in the 4Q380 psalm, which means that the case can well be argued either way.

The next difference in the same verse, i.e., uttering 'the name' or 'the mighty deeds' is more revealing. As Brooke has argued, the 'mighty deeds' fit into the interests of the composer of Psalm 106 because telling about the mighty and marvelous deeds of God is one of the characteristic traits of that Psalm. ${ }^{30}$ However, the same reasoning could perhaps also apply to 4Q380's psalm's use of the 'name' as it is also mentioned a few lines earlier in that psalm (i 5). But it is important for deciding this particular case to note that the compiler of Psalm 106 reveals in another verse that he knew the combination of the terms as the 'name' and 'praises' present in 4Q380. Psalm 106 is characterized by its use of poetic techniques and especially the repetition of word roots to make inclusions. ${ }^{31}$ In verse 47 , which is parallel in expressing the hope for future salvation with the passage we are dealing with, ${ }^{32}$ only expressed in the plural instead of the singular, the hope to be able to acclaim the name and give praises is expressed, i.e., practically the same idea declared in verse 2 , but this time with the original "name", not the "mighty deeds". This future hope clearly has something to do with the Jerusalem cult because it happens after God gathers his people and praising

\footnotetext{
${ }^{30}$ Brooke, "Psalms," 277-78.

31 Although, e.g., Allen, Psalms 101-150, 52-53, draws attention to some of these structural elements, a systematic study also taking into account the way the compiler of Psalm 106 has incorporated his sources into the composition is yet to be made. For use of inclusions and other poetic techniques in general see, e.g., Wilfred G. E. Watson, Classical Hebrew Poetry: A Guide to Its Techniques (2d edition; JSOTSup 26; Sheffield: JSOT Press, 1986).

${ }^{32}$ Hans-Joachim Kraus, Psalms 60-150. A Commentary (transl. Hilton C. Oswald; CC; Minneapolis: Augsburg Fortress, 1989); Gerstenberger, Psalms part 2, 243; also note the connection between these verses.
} 
is so central to it, ${ }^{33}$ but Zion is not mentioned in Psalm 106. An important parallel for this idea is found in Psalm 102:22. It is said there that after God rebuilds Jerusalem it is possible again to: לספר בציון שם יהוה ותהלתו בירושלם "to declare the name in Zion and the praises in Jerusalem". This is the same idea as in the 4Q380 psalm and with a similar verb, which proves that this is not an isolated instance speaking about the declaration of the name but is to be considered the more original pair when talking about the cult.

The next difference between the psalms, still in the same verse, is again a more ambiguous one. It seems that the composer of Psalm 106 has smoothed over the alteration of singular and plural elements present in 4Q380 that was already mentioned before. This is more likely, but as this kind of alteration seems to be a feature of compositional style in 4Q380 this is not a decisive case. A further point to be made on this verse in general is that it is more likely that the compiler of Psalm 106 modified the verse into a more poetic form than that someone took up the nice poetic verse in Psalm 106 and made it poetically worse (the same reasoning applies on the whole to the connecting passages as well).

Verse 3, as already noted, is missing from the 4 Q380 psalm. Again this can be argued either way, but the simplest option is to see verse 3 as an abridgment of the ideas present in the second column of 4Q380. The verse seems out of place in its present place, and this would give a reason for why it was inserted by the compiler of Psalm 106. The connection with the second column of 4Q380 would also help explain the change between the plural and the singular in verse 3, as שמר is in the plural in 4Q380 and ער in the singular just as in verse 3 .

Perhaps the most important differences for deciding which psalm is the source of the other are those in verses 4 and 5 . On the whole in these verses, the compiler of Psalm 106 has modified the more prosaic verses of the 4 Q380 psalm to a more poetic arrangement and he has also changed the verses into a petition for future salvation. The shorter version of $4 \mathrm{Q} 380$ should in this case be viewed as the more original. In the first colon the compiler of Psalm 106 has added עמך "your nation". The people as a unity are at the center of that psalm and emphasizing them is quite logical. However, this addition actually makes the meaning of the colon more ambiguous than in the $4 \mathrm{Q} 380$ psalm.

In the second colon the compiler of Psalm 106 has added בישועתך "your salvation" to make the verse smoother and more complete, as Brooke has said, ${ }^{34}$ and to have another substantive starting with the preposition to

\footnotetext{
${ }^{33}$ Allen, Psalms 101-150, 50-51, connects this idea of the renewal of praise with the return to the land in Jer 33:10-11, 51.

${ }^{34}$ Brooke, "Psalms," 278.
} 
complete the line of them in the surrounding colons. However, with this addition the connection of the verb with the following infinitives is weakened and it would have been more logical in this case to go on with imperfects as in, e.g., Psalm 91:14-16. Furthermore, there is no obvious reason why "your salvation" should have been deleted by the composer of 4Q380 if he was using a source that had it.

The next two colons are practically identical in the two versions. In Psalm גויך your people" in verse 5 has likely been added as a parallel for עמך "your nation" and then there are two slight alterations that would at first seem to favor Psalm 106 as the more original text. The first of these is that the hif. infinitive להראות "cause to experience" is written with a in 4Q380 and without it in Psalm 106. However, both of these forms are well attested in the Hebrew Bible and thus the difference should probably be seen as a matter of orthography rather than an intentional change one way or the other. The other case is that, while the word is in the construct state in both psalms, in 4Q380 it is a masculine and in Psalm 106 a feminine noun. While the change into a masculine from the feminine might be the more common phenomenon, here there is also a good reason for seeing it the other way around. In Psalm 106 the surrounding colons both have a feminine noun with a בישועתך preposition i.e., "in your salvation" and "in gladness". Thus it is quite possible that the compiler of Psalm 106 changed the noun into a feminine form for a closer correspondence with the surrounding verses.

The modifications made by the compiler of Psalm 106 also result in the awkward ending of verse 5 as he needs to fit in the more eclectic group term בחיריך your inheritance" as a parallel for chosen" and thus he has also added another infinitive. That this infinitive is part of the compositional character of Psalm 106 is clear when it is seen that it repeats the root הל present in verse 2 thus creating an inclusion that frames the passage we are dealing with (vv. 2-5) as a section of its own.

As has been seen, the differing readings can be explained in various ways. The fact that the tendencies present in the whole of Psalm 106 can be used to explain nearly all of the differences in the parallel passages is telling, but perhaps not decisive on its own as many of the variants could also be explained the other way around. Thus we need to look at how the text units fit their respective contexts and at what the passage would bring from its former context to the new one if it were the more original of the two. In other words, we search for the motivation behind the use of the quotation. 


\subsection{Interpreting the Texts}

In 4Q380, the passage parallel with Psalm 106 seems well integrated with the available text. It has a connection to the preceding praise of Jerusalem and if column ii is part of the same psalm it fits into the sense, the personal forms and flow of the text. Thus what can be seen does not give an impression of a patchwork of sources, but the lack of the full text does hinder the investigation at this point. If the parallel passage was inserted from Psalm 106 to this psalm there is really only one plausible reason for its use, to offer an explicit answer to the plea left open in Psalm 106. While the text in column i would fit quite well into this idea, the text in column ii does not, because it leads the idea of the psalm in a very different direction. Most telling in this respect however are the details. If this was meant as an answer to the plea in Psalm 106 the changes made to the text do not make sense, and especially leaving out the mention of salvation simply does not fit with this notion as it would have been an integral part of such a response.

When Psalm 106 is viewed a different picture emerges. The parallel passage is not nearly as well integrated with the whole. The links to the other parts of Psalm 106 come mostly from the places where the two psalms differ from each other, which is telling. Furthermore, Psalm 106 is mostly presented in the plural and this passage in the singular created problems for interpreters early on as we can see from the Septuagint and other versions that change it into a plural. This is followed by some modern commentators as well, ${ }^{35}$ but the reason behind the different addresses becomes clear if the passage is seen as a quotation stemming from 4Q380 with its singular address. The passage is part of the frame that encloses the historical narratives in Psalm 106 (vv. 7-46), but it seems to be just a long plea for salvation. However, if Psalm 106 is using the 4Q380 psalm then the plea gets new depth as the connection gives a concrete frame for the longing, i.e., Jerusalem and the cult. The message of Psalm 106 has generally been interpreted in a similar way, i.e., the person longs for God to gather the people again to Jerusalem and is writing in a diaspora or exile setting. ${ }^{36}$ That the same interpretation was common already in antiquity can be seen by the Psalms that follow 106 in two collections, i.e., Psalm 107 in the MT Psalter and Psalm 147 in 4QPs ${ }^{\mathrm{d}}$. Both of these Psalms answer the plea left open in Psalm 106 by telling of God gathering the people to a city, i.e., Jerusalem. Thus the connection with the 4Q380 psalm would give new depth to Psalm

\footnotetext{
35 Artur Weiser, The Psalms. A Commentary (transl. Herbert Hartwell; OTL; Norwich: SCM Press, 1962), 676; Kraus, Psalms 60-150, 315.

${ }^{36}$ Cf. Mitchell Dahood, Psalms III, 101-150 (AB 17A; Garden City: Doubleday, 1970), 76; Allen, Psalms 101-150, 50-52; Kraus, Psalms 60-150, 317; Gerstenberger, Psalms part 2, 244.
} 
106 by voicing the absence of Jerusalem to the audience. If the psalm in 4Q380 had some authority to people then the absence of Zion in Psalm 106 would have been blatantly obvious to them.

One also has to bear in mind that although the theory proposed by Brooke that, because Psalm 106 uses the 4Q380 psalm (and other sources) it would also use 1 Chronicles $16: 34-36^{37}$ is quite controversial, there is no reason to go very far to see that Psalm 106 does use Scripture, as the passages dealing with history surely rely on the Pentateuch. ${ }^{38}$ Thus it is no surprise that it used another source as well. In fact some of the observations made here strengthen the near consensus view among scholars that Chronicles uses Psalm 106, ${ }^{39}$ and not the other way around.

\section{Psalm 106 and Chronicles}

There are many studies dedicated to this question so just a few brief comments are presented here for the sake of establishing a chronology. ${ }^{40}$ The verses of Psalm 106 used in Chronicles (1 Chr 16:34-36) are the first and last two verses of the Psalm (vv. 1, 47-48), i.e., the verses that set the tone for the whole Psalm by laying out its intent and bringing it to a close. Even with the amount of Scripture used in Psalm 106, one would expect at least this frame to come from the compiler of the Psalm, giving his interpretive idea to the material he has used..$^{41} \mathrm{~A}$ connecting point consists of the parallel ideas presented in the passage coming from the 4Q380 psalm and the ending verses of Psalm 106. The use of repetition is a stylistic device of the compiler of Psalm 106 and, as can be observed from the differences bet-

\footnotetext{
${ }^{37}$ Brooke, "Psalms," 279.

${ }^{38}$ This is a clear consensus among scholars, e.g., Weiser, The Psalms, 681; Allen, Psalms 101150, 51; Kraus, Psalms 60-150, 316-17; Gerstenberger, Psalms part 2, 243.

${ }^{39}$ See, e.g., Weiser, The Psalms, 679; Dahood, Psalms III, 67; Allen, Psalms 101-150, 49, 52; Kraus, Psalms 60-150, 322; Gerstenberger, Psalms part 2, 243; Gary N. Knoppers, I Chronicles 10-29. A New Translation with Introduction and Commentary (AB 12A; New York: Doubleday, 2004), 654.

${ }^{40}$ All commentaries treat this question at some length, see, e.g., Sara Japhet, I and II Chronicles: A Commentary (OTL; Louisville: Westminster/John Knox Press, 1993), 312-20; Knoppers, I Chronicles 10-29, 637-61. There are also a number of studies dealing only with the psalm in Chronicles, see, e.g., Trent C. Butler, “A Forgotten Passage from a Forgotten Era (1 Chr. XVI 8-36)," VT 28 (1978): 142-50; Andrew E. Hill, "Patchwork Poetry or Reasoned Verse? Connective Structure in 1 Chronicles XVI," VT 33 (1983): 97-101. More studies like this can be found listed in Knoppers, I Chronicles 10-29, 644.

${ }^{41}$ Verses 1 and 47 probably derive from the compiler, but verse 48 might well be a later addition made during the redaction process of the Psalter as most scholars claim; cf. Dahood, Psalms III, 77; Allen, Psalms 101-150, 50; Kraus, Psalms 60-150, 322; Gerstenberger, Psalms part 2, 23637. If this is true then Brooke's suggestion is even more problematic.
} 
ween 4Q380 and Psalm 106, he has made additions in his source text in keeping with this style. In light of this trait it would be natural to assume that he created a plea parallel to the 4Q380 passage to end the Psalm instead of assuming that there just happened to be two different texts presenting the same idea in the form of a plea.

Turning to the account in Chronicles several additional points can be made. First of all, it is an observable fact that when Chronicles uses Kings the text is often abbreviated (among other redactional methods such as expansion and rewriting) and similar treatment of other material could be anticipated. Second, it must be noted that the passage in Chronicles uses three Psalms (96, 105 and 106) with no text outside these three represented. Therefore, if it is assumed that Psalm 106 is dependent on Chronicles this in practice means that the person responsible for Psalm 106 would have made all three Psalms by cutting the text in Chronicles in three and adding material to them to create Psalms 96, 105 and 106. While not an impossibility this seems, at the least, unlikely, especially as the opposite that the Chronicler has abbreviated three psalms can readily be explained by compositional traits also present elsewhere in Chronicles. The Chronicler frequently emphasizes cultic and temple matters and the part of the Levites, ${ }^{42}$ as is the case also in the section framing the poetic unit. It seems that he gives ancient roots to current practices by implying that was the way things were done already before the exile. Here three post-exilic psalms all having priestly/levitical tones and characterized by the use of earlier Scripture are quoted either partly or fully, but enough for all of them to have been identifiable to an audience from the quotation. The purpose such a text could have served is to give Davidic authority to three late Psalms possibly used in the temple cult of the Chronicler's day.

\section{Relative Dating}

A number of texts dependent on one another have been identified which can help give a relative chronology for the compositions dealt with in this article. It must be emphasized that the interest here is only on a relative chronology because absolute dating of all the following compositions are under debate. The 4Q380 psalm seems to at least allude to some of the last chapters of the Book of Isaiah in the first column (at least 60:2, 65:9 and perhaps 66:10) meaning those verses of the book should be in existence. The psalm has also clearly been influenced by deuteronomistic ideas. Additionally, the

\footnotetext{
${ }^{42}$ See, e.g., Gary N. Knoppers, I Chronicles 1-9. A New Translation with Introduction and Commentary (AB 12; New York: Doubleday, 2004), 80.
} 
psalm emphasizes Jerusalem, the practice of the Law and exhorts at least part of the audience to change their ways, meaning that there seems to be some kind of a rift within the people. Such a centrality of the Law and Jerusalem (it seems to assume that there is a temple in Jerusalem and a Law to be followed by everyone) would fit nicely with the earlier parts of EzraNehemiah ${ }^{43}$ The levitical/priestly tones of Psalm 106 coincide well with the thoughts present in some later parts of Ezra-Nehemiah and Chronicles. One has to especially note the theme of guilt and the defilement of the land found in Nehemiah 9 and Psalm 106:38, the accusation of fraternizing with other nations in verse 35 of the Psalm as well as both of them being poetic national communal confessions in form and using Pentateuchal sources. In light of these features the dating of Psalm 106 should be put at most a generation or so before the Chronicles, but possibly even closer. All of these texts are post-exilic, ${ }^{44}$ and Brooke's observation about the links to Psalm 106 in mid second-century B.C.E. texts (e.g., Sirach, Jubilees and the CD) ${ }^{45}$ as well as similar observances made about the influence of Chronicles on texts around the same time by Gary Knoppers ${ }^{46}$ indicate that the process stops some time before that, but there is no need to be more precise at this point.

\section{Implications for $4 \mathrm{Q} 380$}

There are several implications all this would have on understanding the psalm collection in 4Q380; it first of all means that at least one of the

\footnotetext{
${ }^{43}$ For a comprehensive study on the difficult question about the development of the text of EzraNehemiah, see Juha Pakkala, Ezra the Scribe. The Development of Ezra 7-10 and Nehemia 8 (BZAW 347; Berlin: de Gruyter, 2004).

${ }^{44}$ For Ezra-Nehemiah this dating is obvious. Specifically on the dating of Nehemiah 9, Pakkala, Ezra, 180-84, 210, among others has convincingly argued that it is one of the latest parts of the book if not the whole Hebrew Bible (with some exceptions like Daniel). Dating Chronicles to post-exilic times is not contested, but for a summary of the issues relating to the dating of Chronicles, see Knoppers, I Chronicles 1-9, 101-17. For Isaiah, Joseph Blenkinsopp, Isaiah 56-66. A New Translation with Introduction and Commentary (AB 19; New York: Doubleday, 2003), 43, states that most scholars agree to a date between 522-424 B.C.E. for the chapters that have the verses alluded to. And finally for Psalm 106 the majority of scholars suggest a post-exilic date but several hold for exilic instead, cf. Dahood, Psalms III, 76; Allen, Psalms 101-150, 51-52; Kraus, Psalms 60-150, 317; Gerstenberger, Psalms part 2, 244; Adele Berlin, "Psalms and the Literature of the Exile: Psalms 137, 44, 69 and 78," in The Book Of Psalms: Composition and Reception (ed. Peter W. Flint and Patrick D. Miller, Jr.; VTSup 99; Leiden: Brill, 2005), 74.

${ }^{45}$ Brooke, "Psalms," 280-81, 286-87, 291.

${ }^{46}$ Knoppers, I Chronicles 1-9, 106-11, lists many texts from the Hebrew Bible, apocrypha, pseudepigrapha and Qumran texts, e.g., Daniel, Sirach, 1 Maccabees, Prayer of Manasseh, Temple Scroll, etc.
} 
psalms there was at one point considered inspired or having some authority at least by the group responsible for Psalm 106 because the text is used there as a prophecy of future events. Of interest is that the same psalm might also be quoted in the CD (CD A 9:9, 4Q380 1 ii 3-4). ${ }^{47}$ The links Brooke has drawn between Psalm 106, Chronicles and the CD suggest that they might share some of the same background traditions. That the 4Q380 psalm is possibly used in both Psalm 106 and the CD suggests another link, namely that both authors thought of the psalm as having some authority. Whether any of the other psalms in 4Q380 had such a status can only be guessed at, but, as "Scriptural" psalms and other songs are apparently not mixed in the Qumran psalm collections, it is probable.

There are not many clues as to what kind of a collection 4Q380 would be, but what is there suggests that it might have been a collection of psalms ascribed to different prophets. The psalm dealt with in this paper has links to Isaiah in vocabulary and its exhortative tone is more in line with prophetic texts than Psalms. The use of it in Psalm 106 is also in a sense prophetic as there the passage is expressed as a future hope. To hazard a guess based on the textual links, the psalm might have been in Isaiah's name, which would have explained its authority. Other links to prophetic books are found in some of the vocabulary in the 4Q380 fragments that, while not יום צרה axclusive to prophetic books, is most often found in them such as "the day of distress" ( 7 i 3). A further indication in this direction is the superscription ascribing one of the other psalms in 4Q380 to Obadiah (1 ii 8). While Schuller is right in stressing that we cannot know for certain whether the Obadiah mentioned is the prophet or the steward of the house of Omri, ${ }^{48}$ we can certainly note that the prophet is the far more likely candidate. It is doubtful whether an audience in the Second temple period would have thought about the steward when hearing the superscription; rather the prophet would have been the likely object. Schuller has traced the growing influence of the steward figure, ${ }^{49}$ but it seems to coincide with the identification of the steward with the prophet meaning that if this psalm was connected with the steward it would have been connected to the steward/prophet figure not just the figure of the steward. Thus it seems that there are at least two psalms ascribed to prophets in the collection and while it is perhaps not enough to deduce the intent of the whole original collection, it is the most that can be said on the basis of what is preserved.

\footnotetext{
${ }^{47}$ Joseph M. Baumgarten, "A 'Scriptural' Citation in 4Q Fragments of the Damascus Document," JJS 43/1 (1992): 97, suggests that the quotation in the CD would be derived exegetically from 1 Sam 25:26. This is certainly a possibility, but because the 4Q380 psalm offers a more direct parallel and is in the form of a prohibition, it should be preferred.

${ }^{48}$ Schuller, Non-Canonical, 30.

${ }^{49}$ Schuller, Non-Canonical, 30.
} 


\section{Conclusions}

Several things have been done in this article. First the text of the 4Q380 psalm was analyzed. The extent of the psalm and the flow of the text were established. Then the textual connection to Psalm 106 was thoroughly analyzed and it was discovered that the shorter and in many cases more difficult version of the 4Q380 psalm should be considered a source for Psalm 106. This textual connection helps to illuminate the message of Psalm 106 giving it new depth and it gives an indication of the status of the 4Q380 psalm. However, it is also important in another sense. The 4Q380 psalm is, as far as I know, one of the first texts we have that has been used as an authoritative text in a now canonical text of the Hebrew Bible, but has itself been left outside the canon and is now available to us. There are numerous texts that make use of other canonical writings being among the canonical writings themselves and there are many signs and even explicit mentions of sources in the Hebrew Bible, but in most cases the sources have not survived the tests of time or if they have they are now in the Hebrew Bible. However, here we seem to have a text with several hundred years of history already behind it before it was copied on manuscript 4Q380 - a psalm that is used as an inspired text in a psalm that ended up in the canon. Hopefully further study of the Qumran manuscripts will unearth more evidence of this kind that can be used to further enrich our studies of the way the people compiling some of the now canonical writings used their own sources. 